

\section{DISCLAIMER}

This report was prepared as an account of work sponsored by an agency of the United States Government. Neither the United States Government nor any agency Thereof, nor any of their employees, makes any warranty, express or implied, or assumes any legal liability or responsibility for the accuracy, completeness, or usefulness of any information, apparatus, product, or process disclosed, or represents that its use would not infringe privately owned rights. Reference herein to any specific commercial product, process, or service by trade name, trademark, manufacturer, or otherwise does not necessarily constitute or imply its endorsement, recommendation, or favoring by the United States Government or any agency thereof. The views and opinions of authors expressed herein do not necessarily state or reflect those of the United States Government or any agency thereof. 


\section{DISCLAIMER}

Portions of this document may be illegible in electronic image products. Images are produced from the best available original document. 

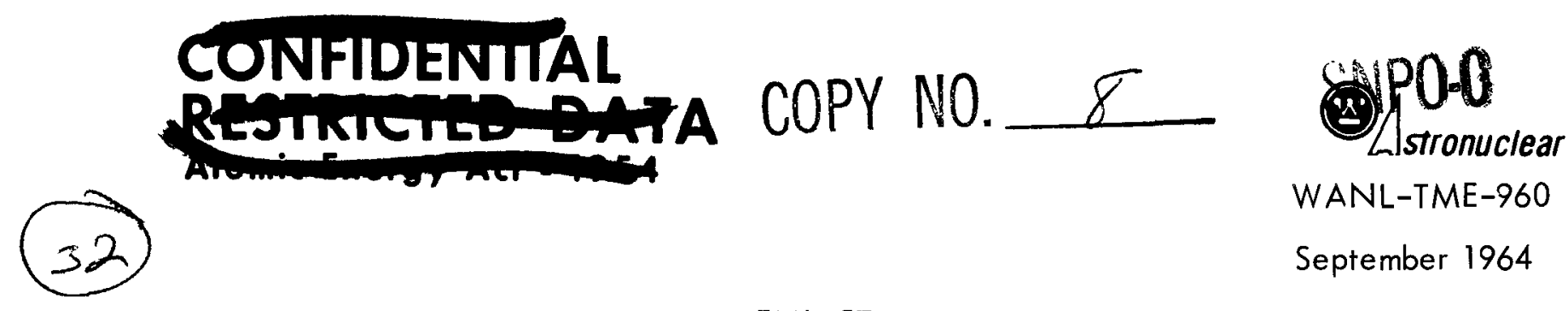

WANL-TME-960

September 1964

EML-57

FINAL REPORT

\section{PLUNGER HOLE STRESS CONCENTRATION AND BINDING TEST}

(Title Unclassified)

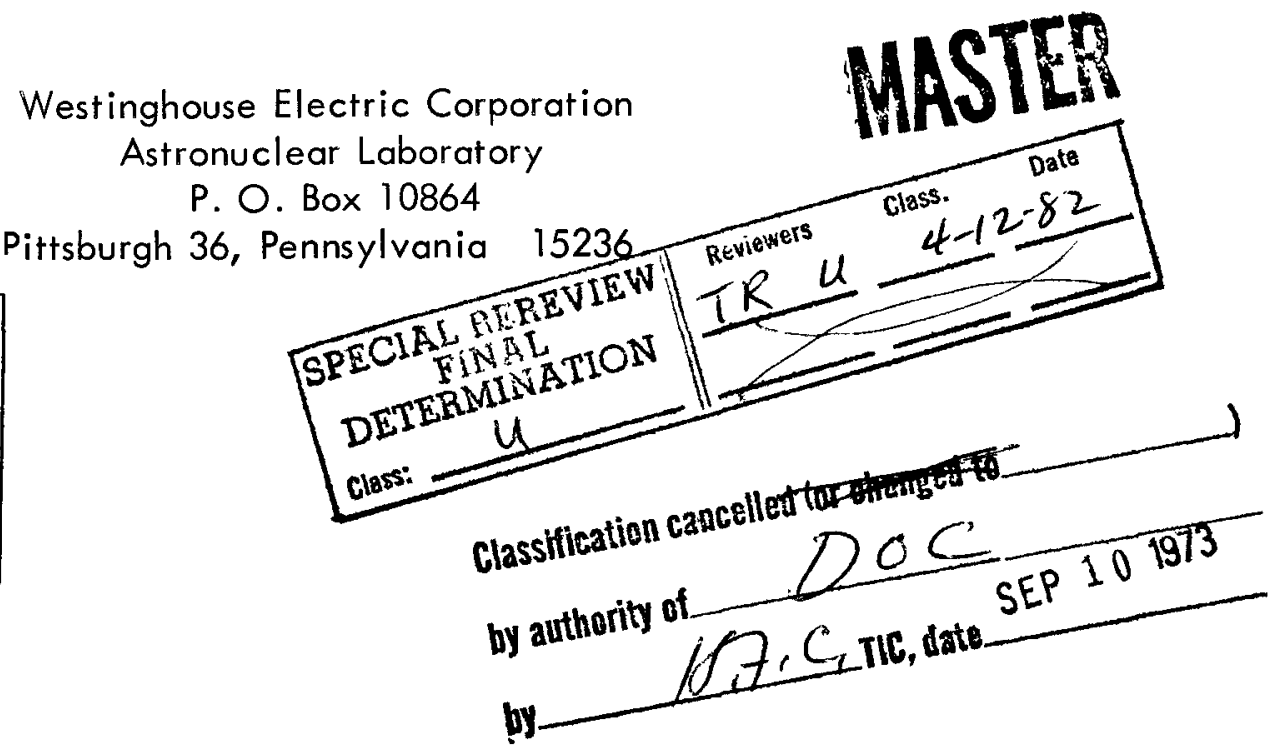

PREPARED BY:

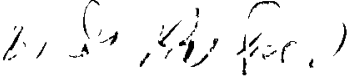

W. G. Parker

Core Components \& Thermal Experiments

NOTICE

This report was prepared as an account of work sponsored by the United States Government. Neither the United States nor the United States Energy Research and Development Administration, nor any of their employees, nor any of their contractors, subcontractors, or their employees, makes any warranty, express or implied, or assumes any legal liability or responsibility for the accuracy, completeness or usefulness of any information, apparatus, product or process disclosed, or represents that its use would not infringe privately owned rights.

E. A. Watjen, Supervisor

Core Components \& Thermal Experiments

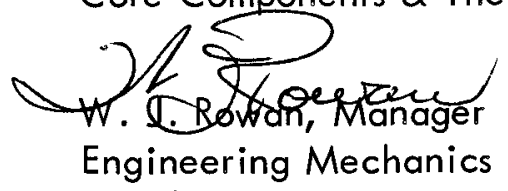

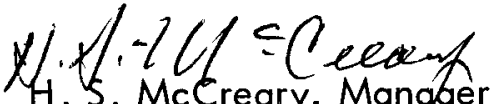

Experimental Engineefing

wa. 0

W. G. Roman, Manager

Reactor Engineering, NERVA Project

/ss

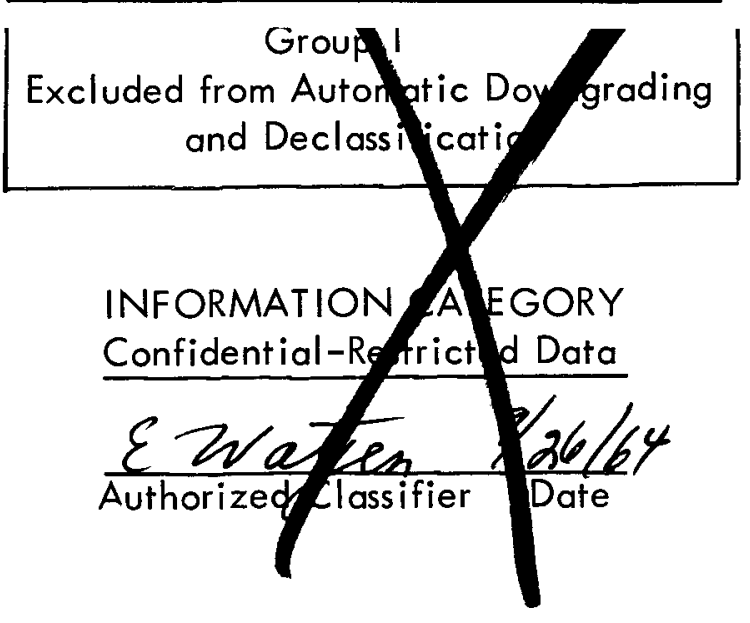

a DSTRIBUTION OF THIS DOCUMENT IS UNLIMITED 


\section{COINTIDENIIAL \\ RESTRICTEZMOATA \\ Atomic Enominand 1054}

TABLE OF CONTENTS

Page

1.0 Summary 1

2.0 Introduction 2

3.0 Data Analysis 3

4.0 Test Description 6

$\begin{array}{lll}5.0 & \text { References } & 7\end{array}$

6.0 Appendix A 8

$\begin{array}{lll}7.0 & \text { Appendix B } & 10\end{array}$

CONFIDENTIA ;

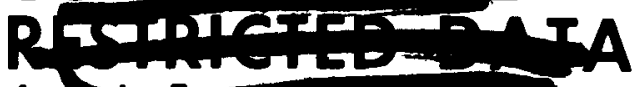

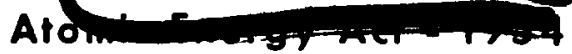




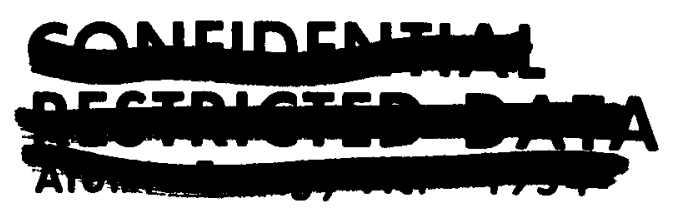

Lstronuclear

WANL-TME-960

\section{LIST OF ILLUSTRATIONS}

$\underline{\text { Figure }}$

$\underline{\text { Page }}$

$1 \quad$ Lateral Support System $\quad 12$

$2 \quad$ Plunger Pin Binding Test - Test Setup 13

3 Load Versus Plunger Friction Force 14

$4 \quad$ Radial Clearance Versus Plunger Friction Force 15

$5 \quad$ Load Deflection Characteristics of an Inner Reflector

16 Spring Cross Section

$6 \quad$ Inner Reflector Butterfly Cutout Section 17

$7 \quad$ Plunger Pin Binding Test 18

$8 \quad$ Plunger Pin Binding Test 19

9 Plunger Hole Diametral Change (First Cycle) 20

I0 Plunger Hole Diametral Change (Second Cycle) 21

11 Plunger Hole Strain Locations 22

$12 \quad$ Plunger Pin Binding Test (No Pin In Hole) 23

13 Plunger Pin Binding Test (Pin Installed) 24

14 Plunger Pin Binding Test (Plunger Pin Installed in 25

15 Plunger Pin Binding Test (No Pin In Hole) 26

$\begin{array}{lll}\text { Table } 1 & \text { NRX-A Plunger Pin Binding Test } & 27\end{array}$

Table II Plunger Hole Diametral Change 28

Table III Plunger Hole Diametral Change 29 


\subsection{SUMMARY}

1.1 Structural testing of an NRX-Al inner reflector cylinder indicated deformations of sufficient magnitude to possibly interfere with plunger pin movements during reactor cooldown. Tests have therefore been performed to establish a relationship between plunger hole/pin radial clearances and the force required to overcome the interference friction should pin binding occur when a cross section of the inner reflector spring cutout region is subjected to simulated reflector static loading conditions.

1.2 Results from these tests indicate that under a simulated reflector static pressure loading of 190 psig pressure, plunger forces of approximately $130 \mathrm{lb}$ and $55 \mathrm{lb}$ for radial clearances less than $.001 \mathrm{in}$. and .0014 in., respectively, are required to overcome the interference friction resulting from pin binding. For radial clearances greater than .002 in., plunger hole deformations do not interfere with plunger pin movement。

1.3 As a supplement to the test data presented in this report, additional testing was performed, the results of which are presented in Appendix B. Tests were performed to establish the force required to overcome the interference friction between a plunger pin and a plunger hole for a plunger hole/pin radial clearance of 0.0003 inch, and to determine the change in plunger hole diameter (no plunger pin used) and the strain adjacent to the plunger hole for various axial loadings. Results from these tests indicate that for a $12,000 \mathrm{lb}$ compressive load (equivalent to $149 \mathrm{psi}$ pressure on the inner reflector) a force of approximately $98 \mathrm{lb}$ is required to overcome the interference friction between the plunger pin and the plunger hole. 


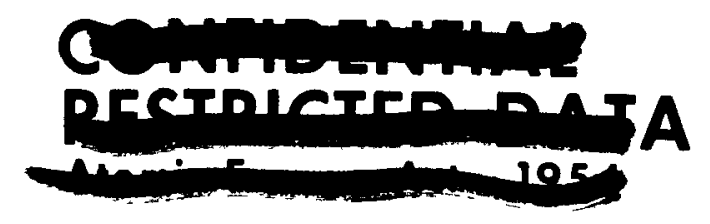

\section{(w) \\ Lstronuclear \\ WANL-TME-960}

\subsection{INTRODUCTION}

2.1 The NRX-A lateral support system (Figure 1) is used to bundle the reactor core during steady-state operation, to provide a distributed seal system about the core periphery and to absorb static and dynamic lateral loads to and from the core during shipping and engine operation. One of the primary components of the lateral support system is the graphite plunger pin. The function of the plunger pin is to transmit the bundling force from the lateral support springs to the reactor core, to transmit the core lateral loads to the lateral support springs, and to positively seat the seal segments (Reference 1).

2.2 Structural evaluation tests previously performed on an NRX-A1 inner reflector graphite cylinder have indicated radial deformation exceeding $0.1 \mathrm{in.} \mathrm{under} \mathrm{a}$ 200 psig uniform external pressure environment (Reference 2). This radial deformation could be of sufficient magnitude to result in excessive deformations of the plunger holes (Figure 1) thereby restricting the movement of the plunger pins during reactor cooldown. A series of tests were, therefore, performed to establish the relationship between plunger hole/pin clearances and the force required to overcome interference friction should the plunger pins bind under a simulated inner reflector loading environment (Figure 2).

2.3 Accurate design analysis of the inner reflector cylinder spring cutouts (Figure 1) is practically impossible because of geometrical discontinuities. Structural testing of an NRX-Al inner reflector cylinder (Reference 2) has indicated stress concentrations existing in the cutout sections. A series of tests have, therefore, been initiated in an attempt to define an approximate strain distribution for the inner reflector spring sections. Only preliminary testing has been completed to date, the results of which are briefly discussed herein. 


\subsection{DATA ANALYSIS}

3.1 Structural tests previously performed on an NRX-A1 inner reflector cylinder (Reference 2) indicated deformation (200 psig uniform external pressure) of sufficient magnitude to possibly interfere with plunger pin movements during reactor cooldown. A series of tests have, therefore, been performed to establish the force required to overcome the interference friction should pin binding occur when a cross section of the inner reflector spring cutout region is subjected to simulated reflector static loading conditions (Figure 2).

3.2 Data obtained from this series of tests are presented in Table I. The test data is described graphically in Figures 3 and 4. For each increment of compressive loading applied to the test specimen, the force required to initiate plunger pin movement (plunger friction force) was determined for various radial clearances (the radial clearance is defined to be the gap existing between the plunger pin and the plunger hole when the spring cross section is under no compressive loading).

3.3 The test data indicate that for radial clearances less than .001 in., a force of approximately $130 \mathrm{lb}$ is required to overcome the interference friction between the plunger pin and the plunger hole when the spring cross section is subjected to a $15,300 \mathrm{lb}$ compressive load. (The $15,300 \mathrm{lb}$ load produces approximately the same average deformation characteristics of the pin holes as a 190 psig (NRX-A maximum reflector pressure differential) pressure would when acting on the external surface of the inner reflector.) For a radial clearance of $.0014 \mathrm{in}$. and 15,300 lb axial load, a plunger force of $55 \mathrm{lb}$ is required. For clearances greater than $.002 \mathrm{in}$. and $15,300 \mathrm{lb}$ axial load, no interference with plunger pin movement was obtained during deformation of the spring cross section. Test data obtained for different axial loads other than that discussed is described in Figure 3. Also, Figure 4 describes the test data by showing the

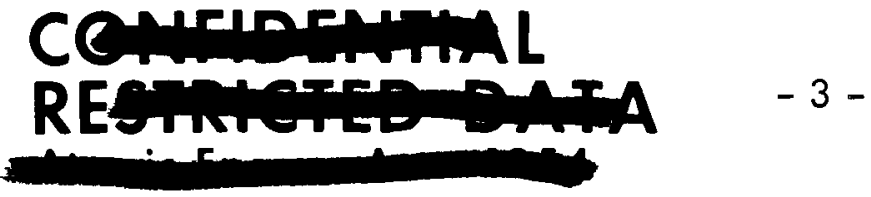


variation of the plunger friction force with respect to radial clearances for different compressive loads.

3.4 Figure 3 indicates in general that as the clearance is increased, the plunger force decreases. Some variations can be seen but should be expected since the clearance between the pin and hole varied through the thickness of the test block. The radial clearances were determined by measuring the diameter of the plunger holes at various depths through the spring section and then the diameters of the pins. The dimensions for each component were averaged and half the difference between the two averages computed. The hole measurements, however, showed that the minimum diameters varied approximately .0006 with respect to the average values plotted on Figures 3 and 4. The same plunger pins were used for all tests, however, the radial clearances were varied by reaming the plunger holes. Therefore, the variables of plunger pin wear and ellipticity of the pins and holes were not considered during this test series. (The diameters of the plunger pins did not significantly change during any test. However, the surfaces of the pins became polished which would influence the friction force.)

3.5 From this test series, it can be concluded that under the simulated inner reflector static pressure loading (190 psig) plunger forces of approximately $130 \mathrm{lb}$. and $55 \mathrm{lb}$. for radial clearances less than $.001 \mathrm{in}$. and .0014 in. respectively are required to overcome the interference friction resulting from pin binding. For radial clearances greater than .002 in., the plunger hole deformations do not interfere with pin movement.

3.6 In conjunction with the above series of tests, data has also been generated describing the load-deflection characteristics of a section of the inner reflector cylinder containing the spring cutout (Figure 5). The test component was 

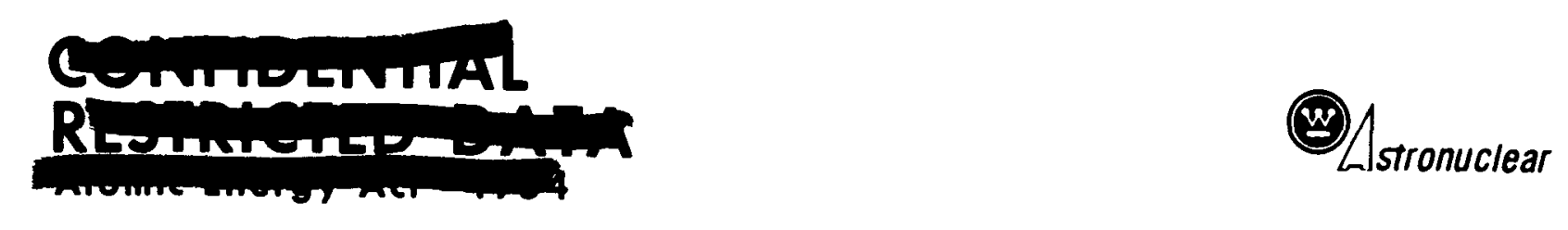

WANL-TME-960

cycled to a $30,000 \mathrm{lb}$ load (approximately 90 percent of ultimate load) five times; the specimen was kept at the minimum $(0 \mathrm{lb})$ and maximum $(30,000 \mathrm{lb})$ loads for a one minute period for each cycle. These data represent the approximate hysteresis characteristics that can be expected for the inner reflector in the spring cutout region. (The specimen used to determine the hysteresis curves had been previously cycled to $20,000 \mathrm{lo}$ load and to $26,000 \mathrm{lb}$ load twice.)

3.7 As previously stated, testıng has been initiated to establish an approximate strain pattern for the inner reflector spring cutout region. Tests will also be performed to establish a stress concentration factor for the inner reflector plunger holes. Testing to date has included the establishment of the load required to produce failure of the simulated spring cutout region and the checkout of the strain gages (Figure 6) mounted on the test specimen. The load required to produce failure of the spring cutout region was $35,500 \mathrm{lb}$. During checkout testing of the strain gages, it was determined that the deformation of the test specimen was greater than the allowable for some of the strain gages used thus resulting in gage failure. (Since the purpose of this test was to establish approximate stress concentration factors for the spring cutout region, strain gages having small gage lengths (.05. in.) were chosen for initial testing.) It is, therefore, recommended that strain gages capable of withstanding $.005 \mu \mathrm{in}$./in. be installed on the test specimen. The remainder of this test series will be completed during contract year 1965. 


\subsection{TEST DESCRIPTION}

4.1 Tests to determine the relationship between plunger hole/pin clearance and the force required to overcome the interference friction, should pin binding occur during reactor cooldown, have been performed. In addition, tests to define the strain distributions in an inner reflector spring section have been initiated.

4.2 Evaluation of the plunger hole/pin clearances was accomplished using a simulated inner reflector spring cutout section (Figure 2). (Appendix A) Compressive loads simulating the inner reflector stress distribution were applied to the cutout section (Figure 2). At each increment of axial loading the force required to initiate movement of the plunger pin in the plunger hole was determined. This data was taken during both increasing and decreasing load. Deflection of the test component was also monitored during testing.

4.3 At present, only initial testing has been performed to determine the strain distribution in an inner reflector spring cutout section (Figure 6). Therefore, no detailed test description will accompany this report since the accumulation of additional data could alter the present test procedure.

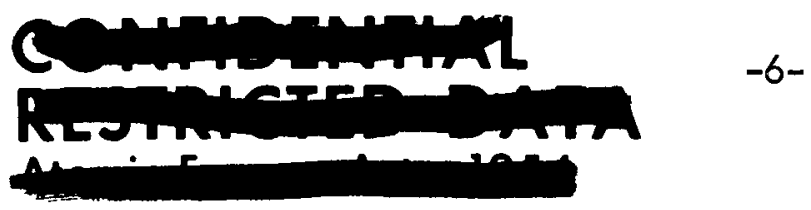




\subsection{REFERENCES}

5.1 "NRX-A Block 1 Mechanical Design" prepared by Mechanical Design, Westinghouse Astronuclear Laboratory.

5.2 "Structural Evaluation of the Inner Reflector" prepared by W. G. Parker; WANL-TME-768, Westinghouse Astronuclear Laboratory. 


\title{
6.0 APPENDIX A
}

\author{
EVALUATION OF NRX-A PLUNGER PIN OPERATION \\ PROCEDURE FOR EVALUATING PLUNGER PIN CLEARANCES
}

\subsection{PURPOSE}

6.1.1 The purpose of this test was to determine a relationship between plunger hole/pin clearances and the force required to overcome the interference friction between the pins and holes under simulated reactor static loading conditions.

\subsection{OBJECTIVES}

6.2.1 To determine the force required to remove the plunger pins from the plunger holes under different section compressive loads.

6.2.2 To determine a load deflection curve for the spring cutout section.

6.2.3 To determine the load required to fail a simulated impregnated spring cutout in the inner reflector.

\subsection{TEST COMPONENTS}

6.3.1 The test components were a simulated impregnated inner reflector spring cutout section (previously used during EML-30 tests) and reactor grade plunger pins.

\subsection{TEST PLAN}

6.4.1 All components were inspected by WANL Quality Control Department prior to festing.

6.4.2 Clip gages were mounted on the spring sections as shown in Figure 2.

6.4.3 Asbestos was provided on the specimen end to assure uniform loading.

6.4.4 The test specimen was placed in the Wiedemann-Baldwin machine with the plunger holes in the direction of loading (Figure 2). 


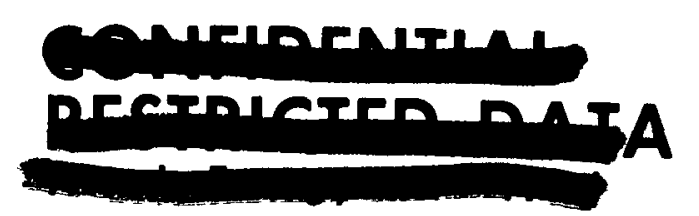

\section{(w) \\ Lstronuclear \\ WANL-TME-960}

6.4.5 Plunger pins were placed in the specimen plunger holes. An initial reading of the force required to remove the pin under zero compressive load was taken using a Chatilon gage.

6.4.6 A dial gage was mounted adjacent to the test specimen to determine cutout deflection.

6.4.7 The test componerts were loaded in 2,000 lb. increments until complete binding or $20,000 \mathrm{lb}$. was reached. The force required to remove and re-insert the plunger pin, (A Chatilon gage and a load cell in series with a pneumatic cylinder was used to determine pin force; dial gage, and clip gage readings were recorded at each load increment.

6.4.8 Step 6.4.7 was repeated for four times.

6.4.9 After step 6.4.8 is completed, the specimen was loaded to failure with the plunger pins inserted.

6.5 DATA REQUIRED

6.5.1 Force to remove and re-insert plunger pins.

6.5.2 Axial load to cause failure of spring cutout section.

6.5.3 Deflection of block under compressive loading. 


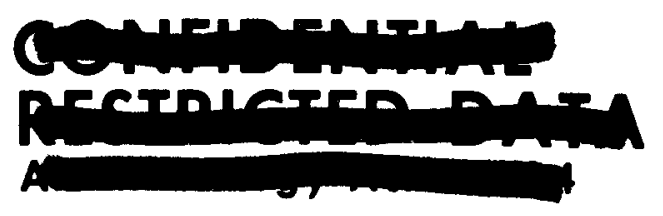

Lstronuclear

WANL-TME-960

\subsection{APPENDIX B}

PLUNGER HOLE STRESS CONCENTRATION AND BINDING TEST

\subsection{PLUNGER PIN BINDING TEST}

7.1.1 Tests were performed to establish the force required to overcome the interference friction between a plunger pin and a plunger hole under simulated inner reflector static loading conditions. The plunger hole/ pin diametral test clearance was .0006 inch. The test component and test setup is described in Figure 2 (no clip gages used). Compressive loads $(12,000 \mathrm{lb})$ simulating the average plunger hole deformation characteristics produced by the NRX-A2 reflector pressure drop (I49 psi) were imposed upon the specimen. The force required to overcome the friction force between the plunger pin and the plunger hole was recorded at various load increments.

7.1.2 Test data obtained describing the friction force is presented in Figures 7 and 8. Figure 7 was the first loading cycle to $12,000 \mathrm{lb}$ while

Figure 8 represents the second cycle. Test data indicate friction forces of approximately $98 \mathrm{lb}$ for the first cycle and $96 \mathrm{lb}$ for the second cycle at $12,000 \mathrm{lb}$ load. Diametral measurements taken of the plunger hole and the plunger pin indicated no appreciable change resulting from these tests.

\subsection{PLUNGER HOLE DIAMETRAL CHANGE}

7.2.1 Tests were performed wherein the change in plunger hole diameter (in the direction of loading) was determined with respect to compressive loading. Data obtained from these tests is presented in Tables II and III. Figures 9 and 10 describe the data graphically. For the first cyclic loading to $12,000 \mathrm{lb}$, a permanent deformation of .0006 in. was determined for the plunger hole; the second cyclic loading to 


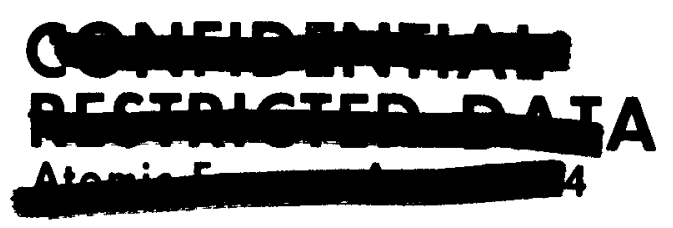

$12,000 \mathrm{lb}$ produced no further permanent deformation. The maximum deformation from both cycles at $12,000 \mathrm{lb}$ was approximately .0033 inch. The plunger hole diameter measurement was repeated 12 hours after the test was performed to observe whether any creep had occurred. The results were similar to those previously taken.

\subsection{PLUNGER HOLE STRAIN MEASUREMENTS}

7.3.1 Tests were performed to determine the relationship between compression load and specimen strain with and without a plunger pin inserted in the plunger hole. Strain gages were mounted on the test specimen as shown in Figure 11. Test data describing the strains adjacent to the plunger hold and at distances from the hole are shown in Figures 13, 13, 14, and 15. These gages indicate strain levels of approximately $1.700 \mu \mathrm{in}$./in. with a plunger pin inserted and $2,500 \mu$ in./in. without a plunger pin inserted for a load simulating the maximum NRX-A2 pressure differential (149 psi). These data demonstrate approximately the influence on inner reflector stresses of the plunger pins. These data correlate well with those obtained during previous inner reflector buckling tests (Reference 2)。

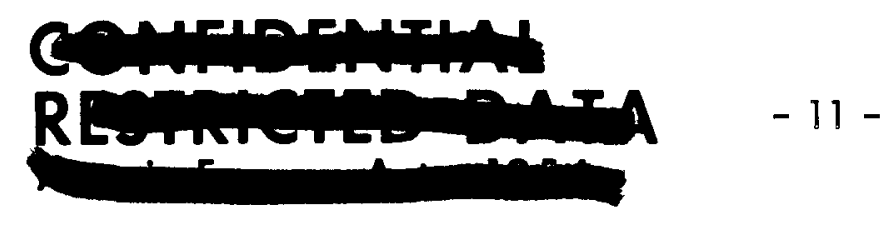




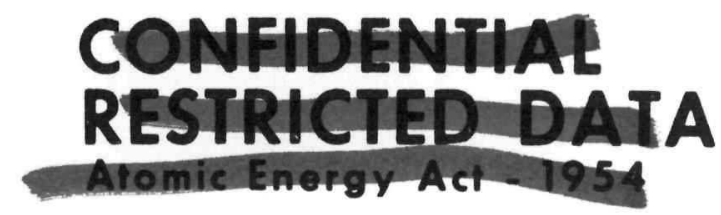

(ㅅ)

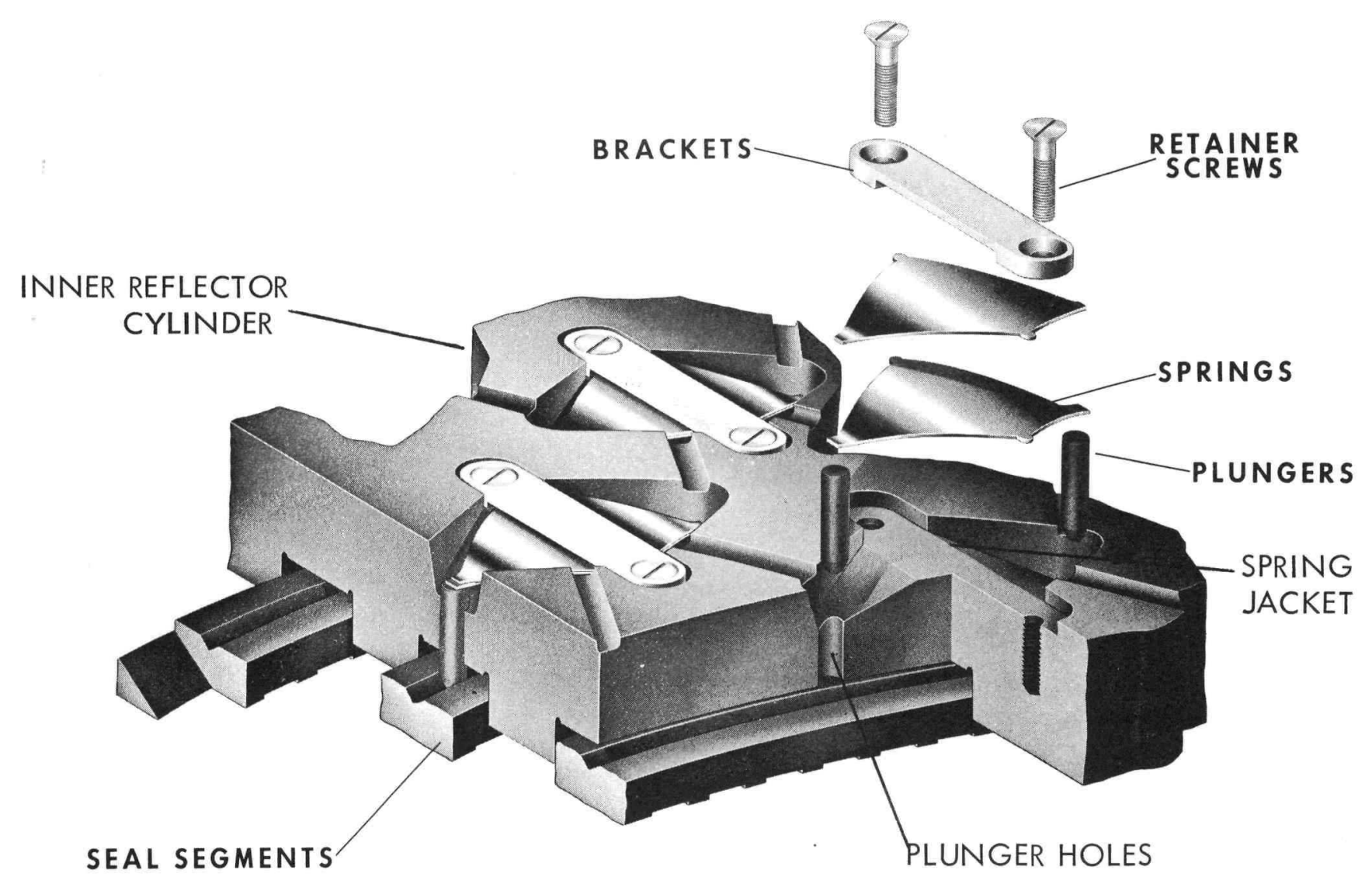

FIGURE 1

LATERAL SUPPORT SYSTEM 


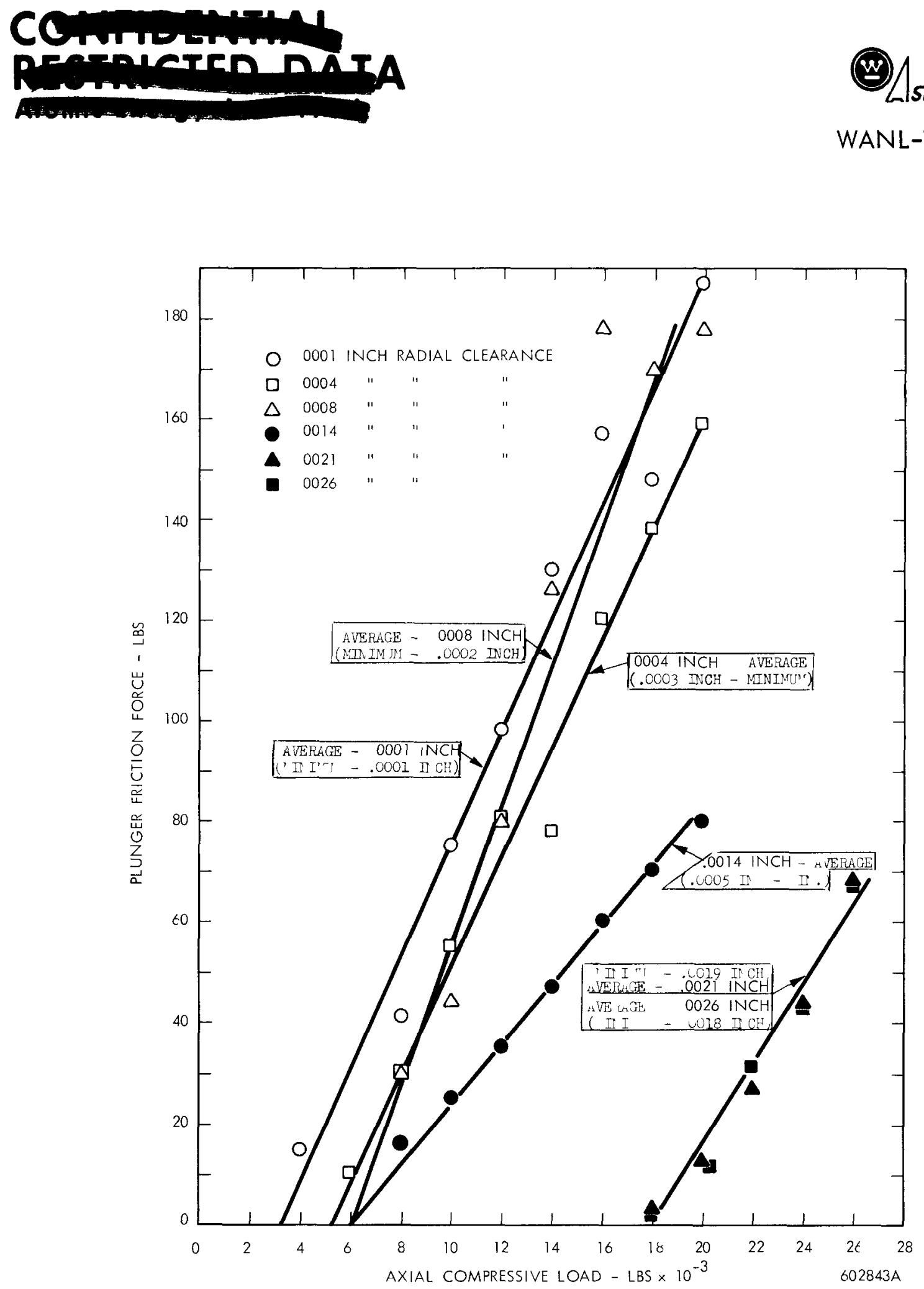

FIGURE 3

AXIAL LOAD VERSUS PLUNGER FRICTION FORCE

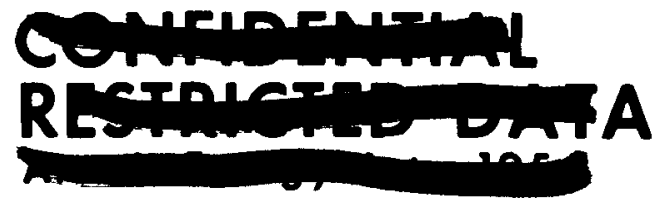



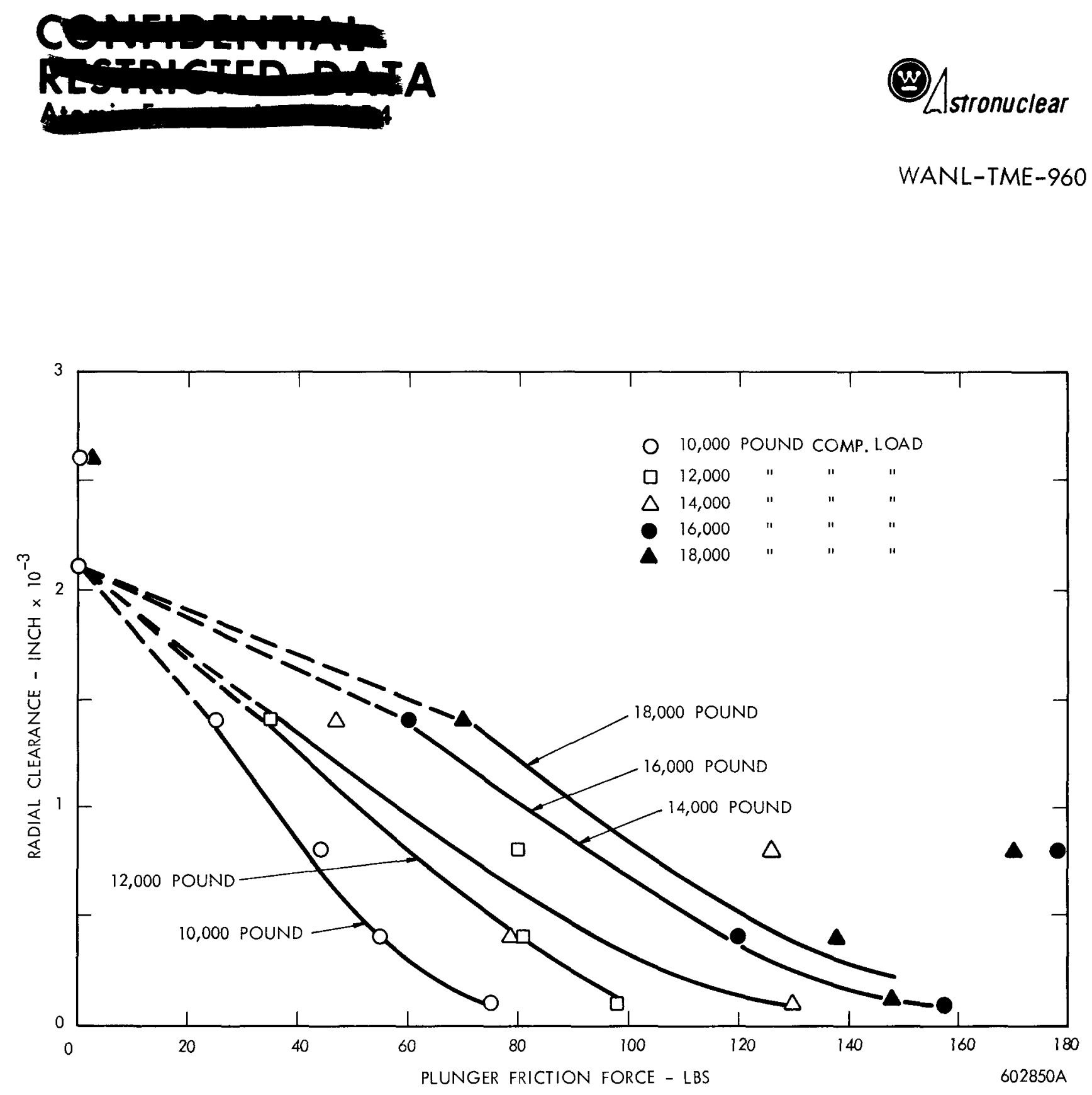

FIGURE 4

RADIAL CLEARANCE VERSUS PLUNGER FRICTION FORCE FOR VARIOUS COMPRESSIVE LOADS

\section{CONEIDENITIL}




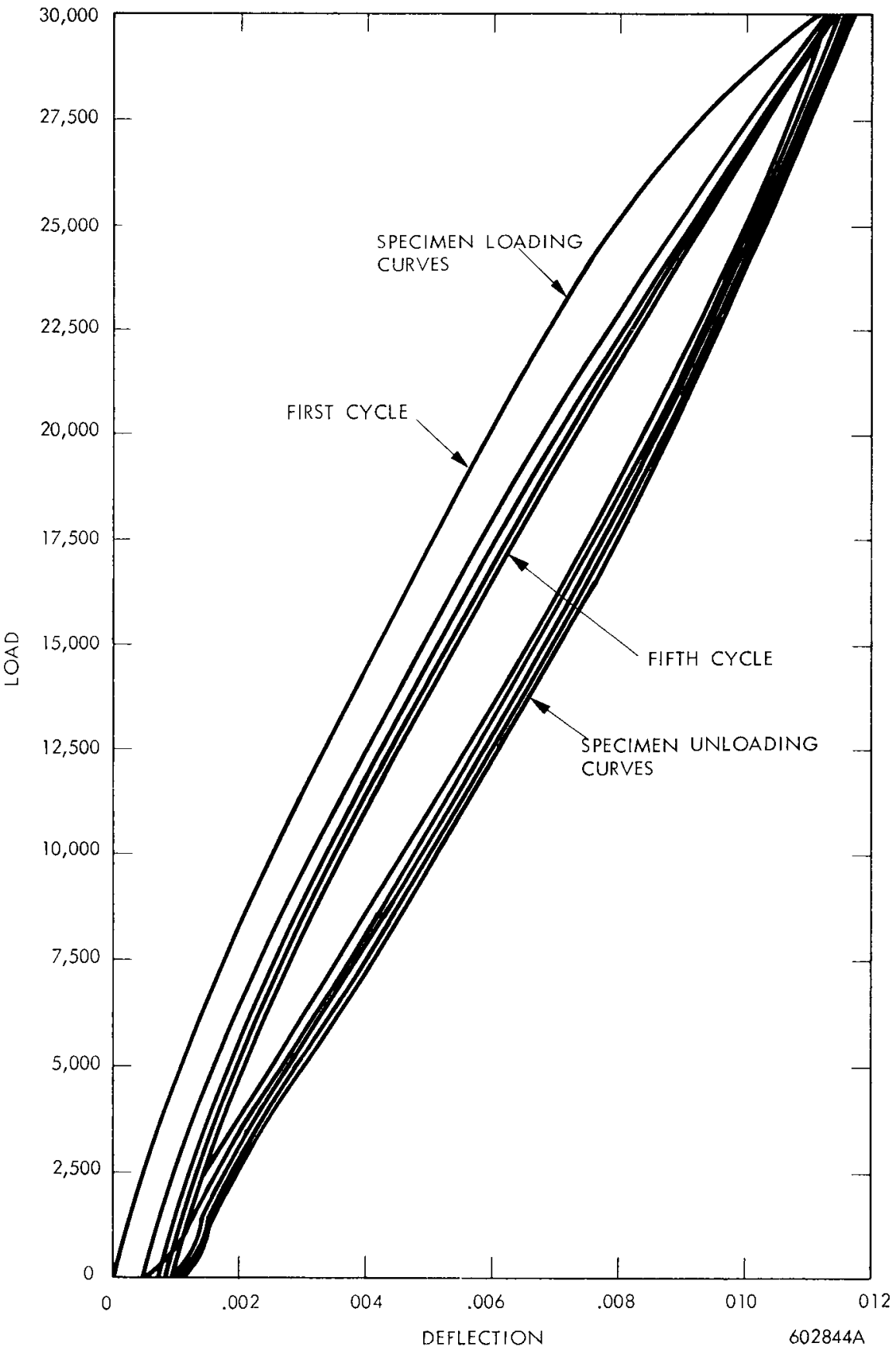

FIGURE 5

LOAD DEFLECTION CHARACTERISTICS OF AN INNER REFLECTOR SPRING CROSS SECTION

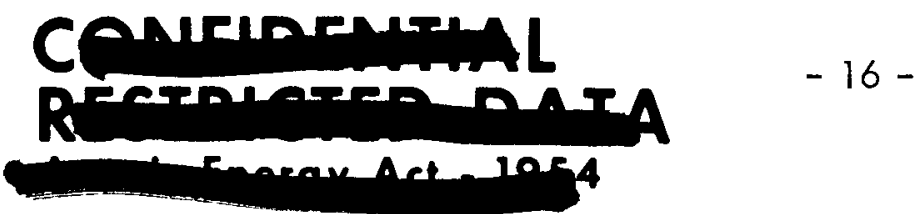



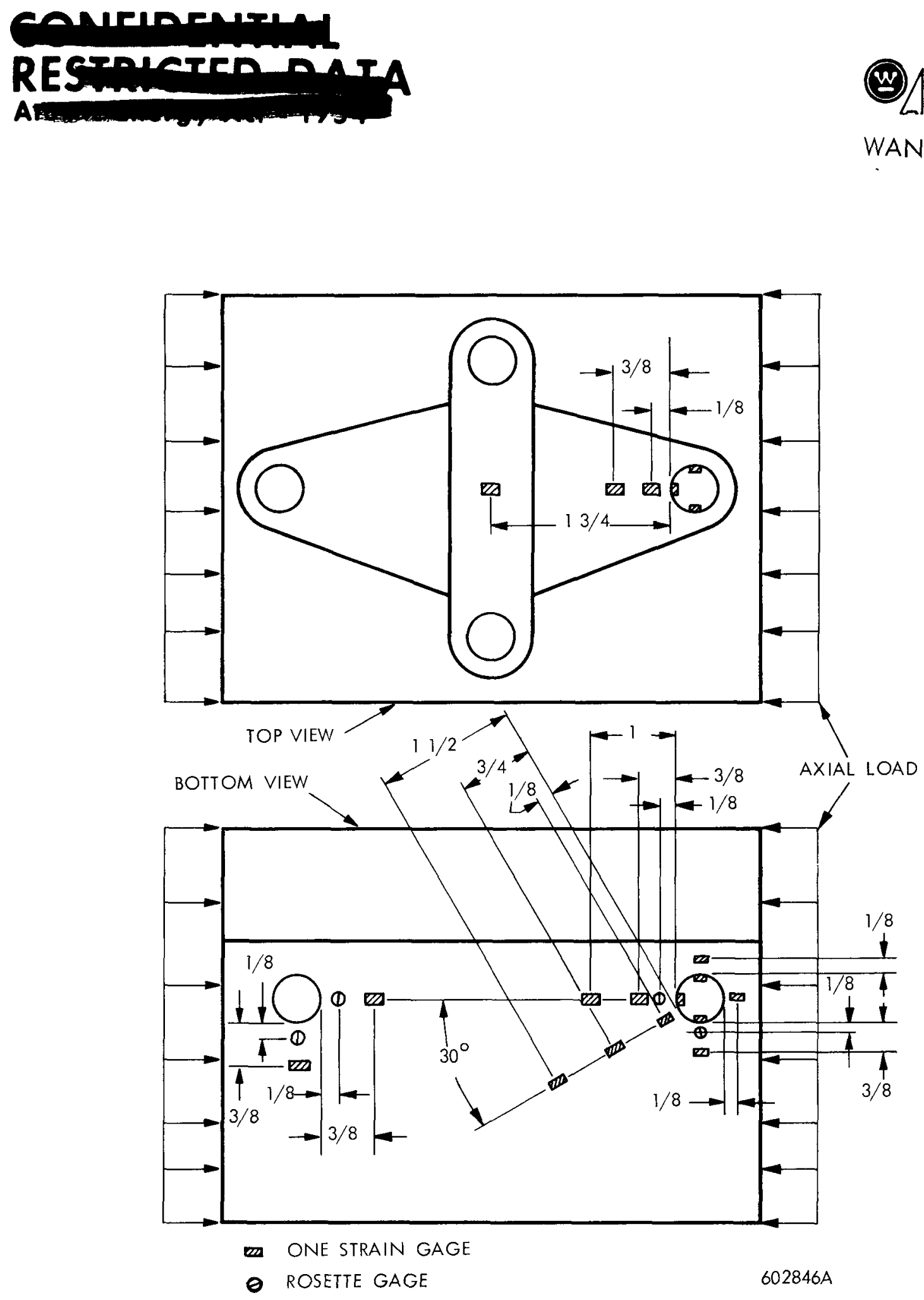

FIGURE 6

INNER REFLECTOR SPRING CUTOUT SECTION

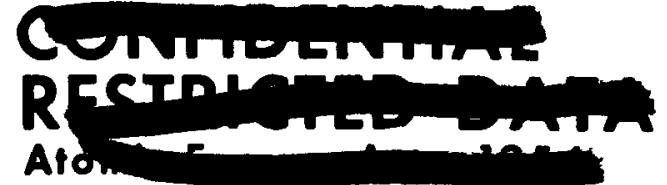



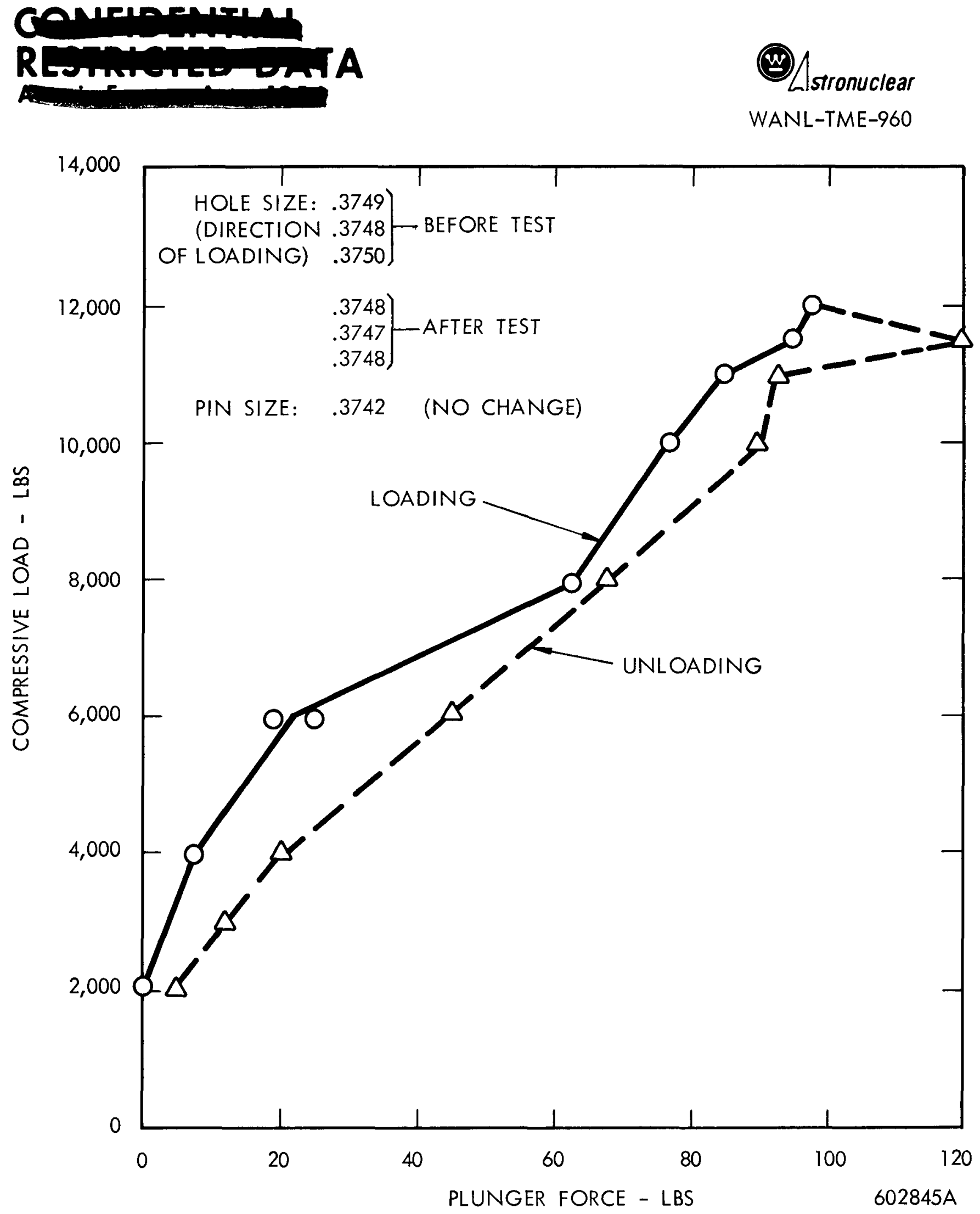

FIGURE 7

PLUNGER PIN BINDING TEST 
cons

Remertorent

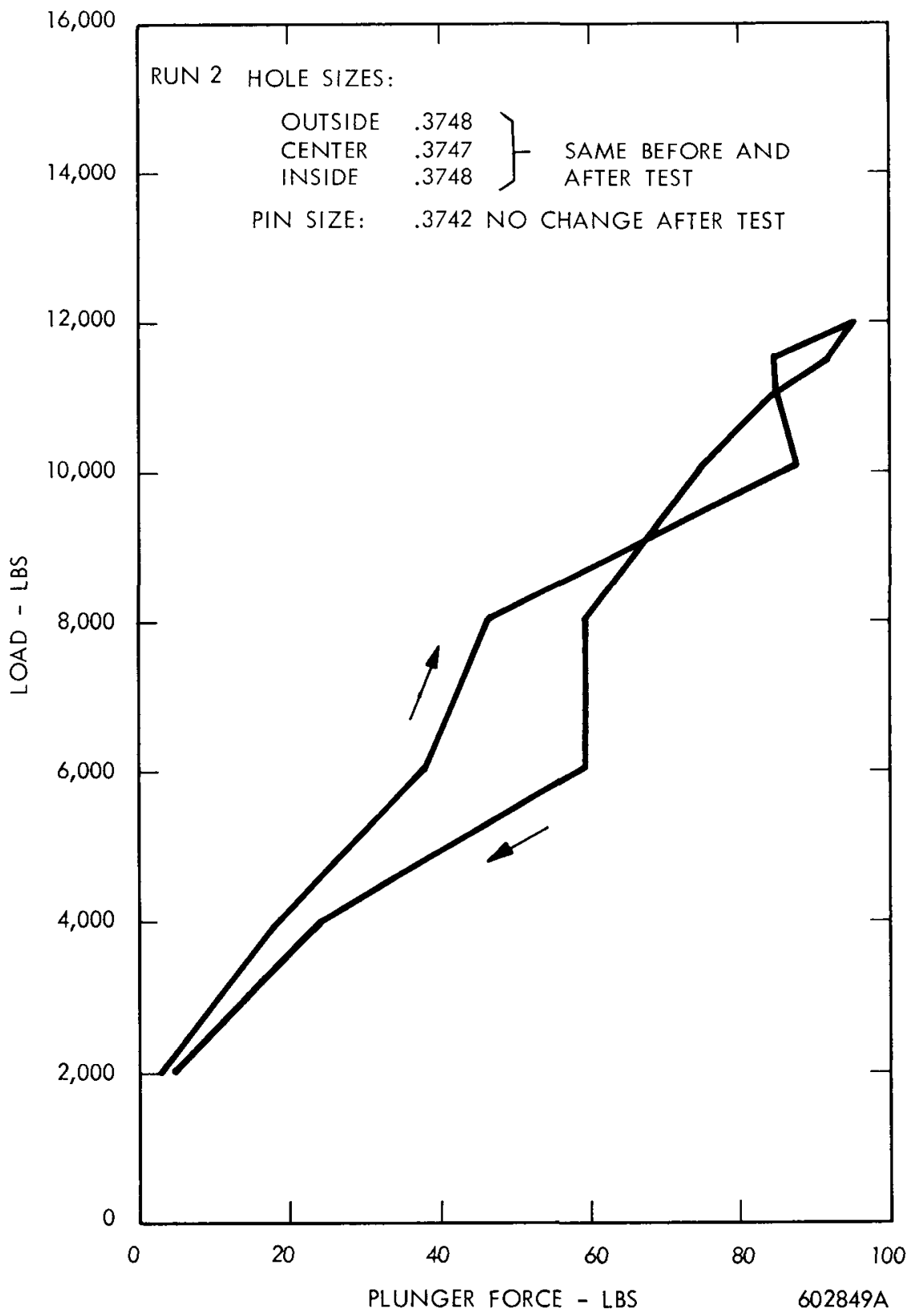

FIGURE 8

PLUNGER PIN BINDING TEST

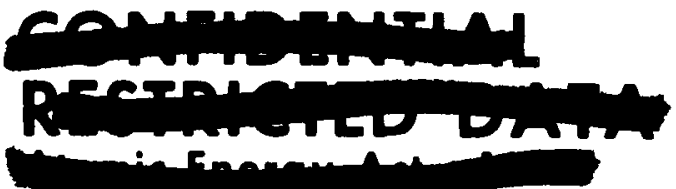



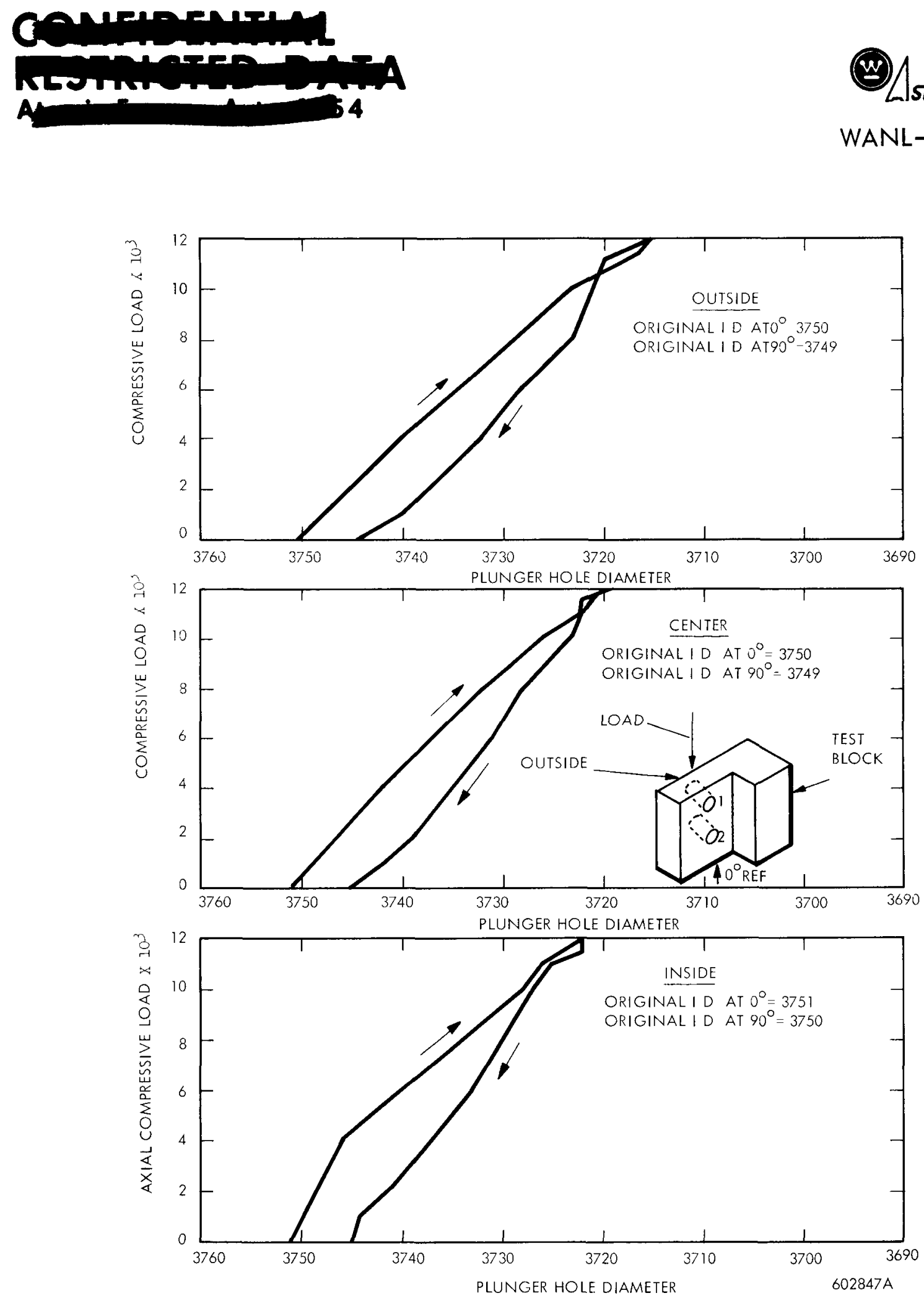

FIGURE 9

PLUNGER HOLE DIAMETRAL CHANGE (FIRST CYCLE) 

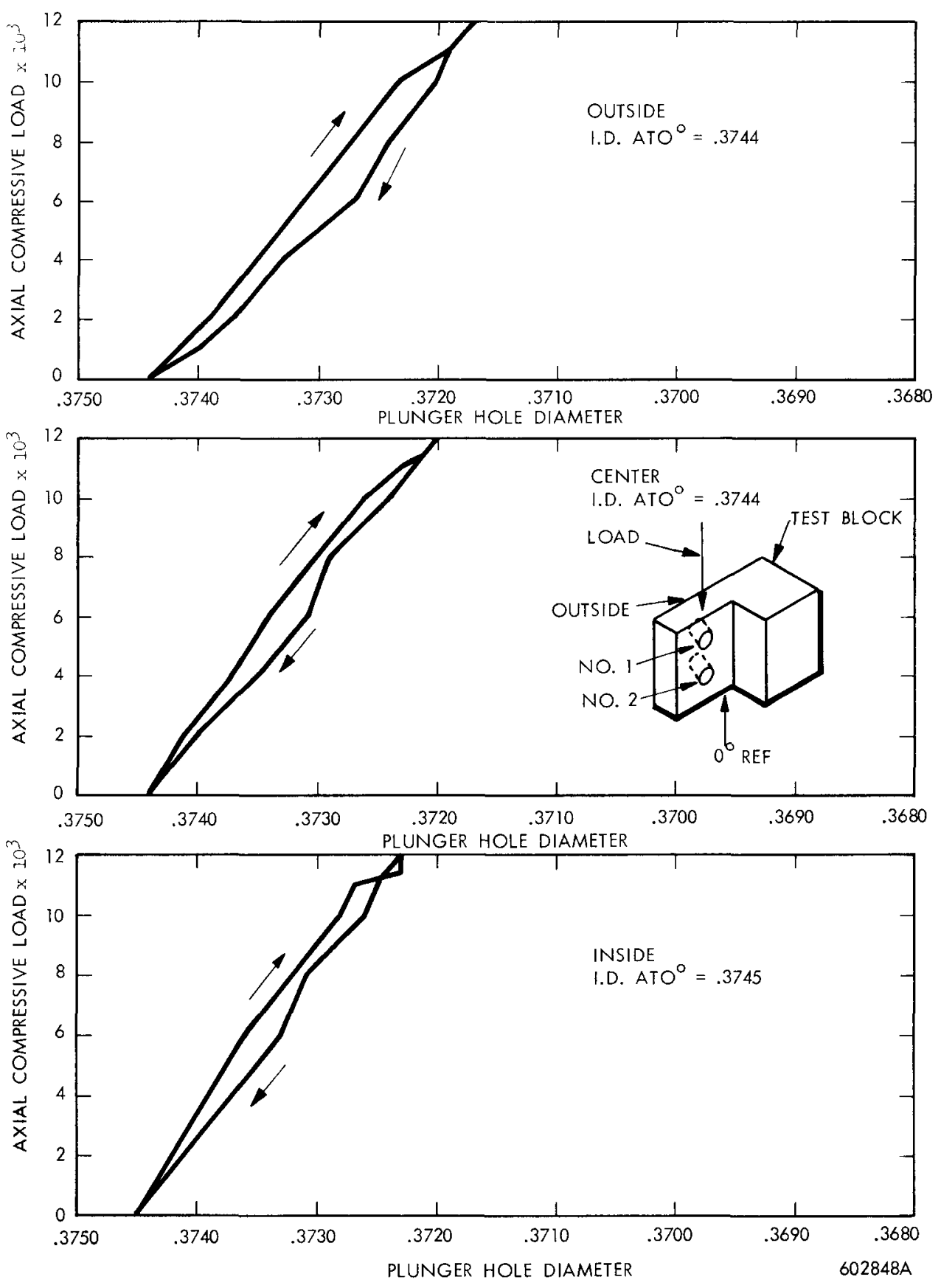

FIGURE 10

PLUNGER HOLE DIAMETRAL CHANGE (SECOND CYCLE) 


\section{CONFIDENTHAL \\ RESTRICTED DATA \\ Atomic Energy-Act 1954}

(w) stronuclear

WANL-TME-960

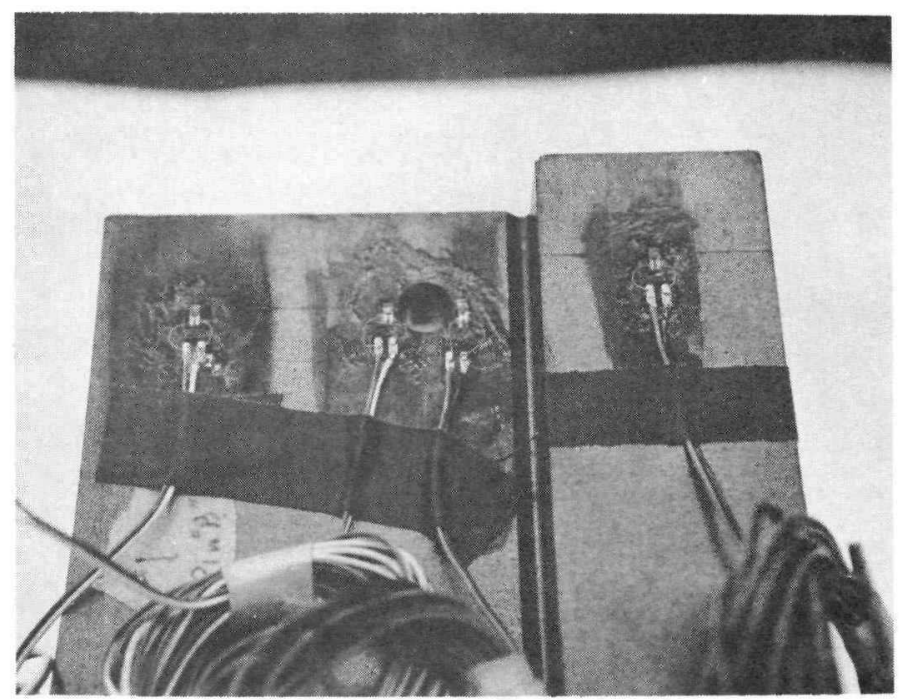

FIGURE 11

PLUNGER HOLE STRAIN LOCATIONS 

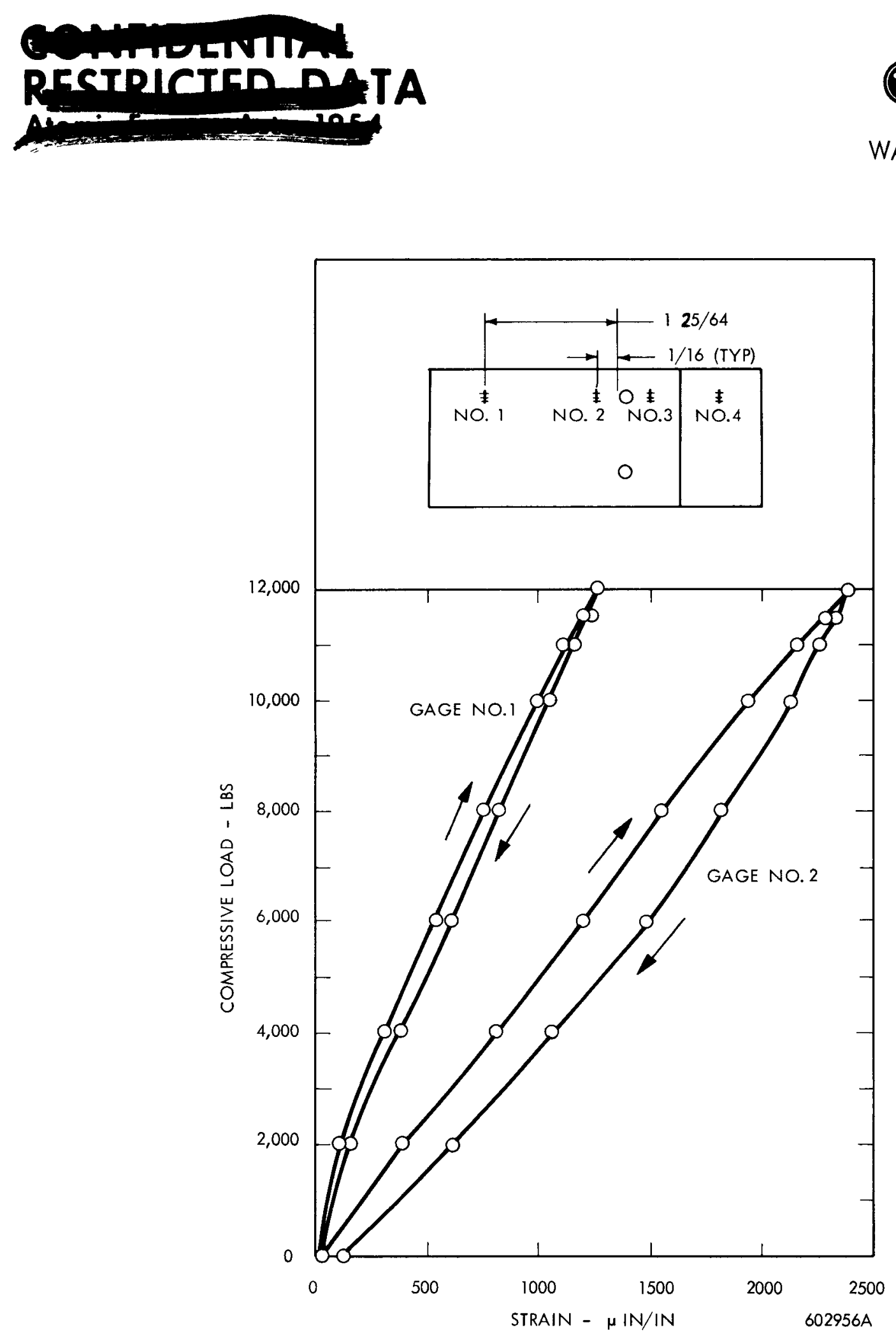

FIGURE 12

PLUNGER PIN BINDING TEST (NO PIN IN HOLE)

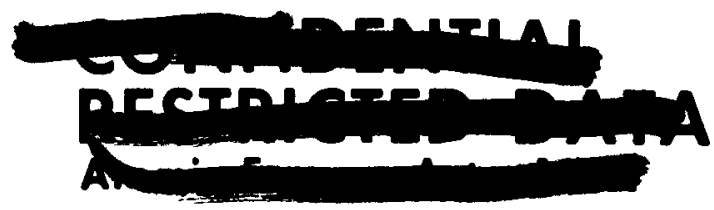



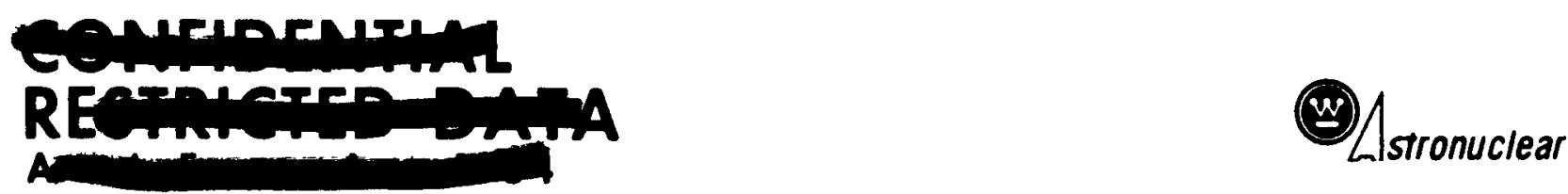

WANL-TME-960

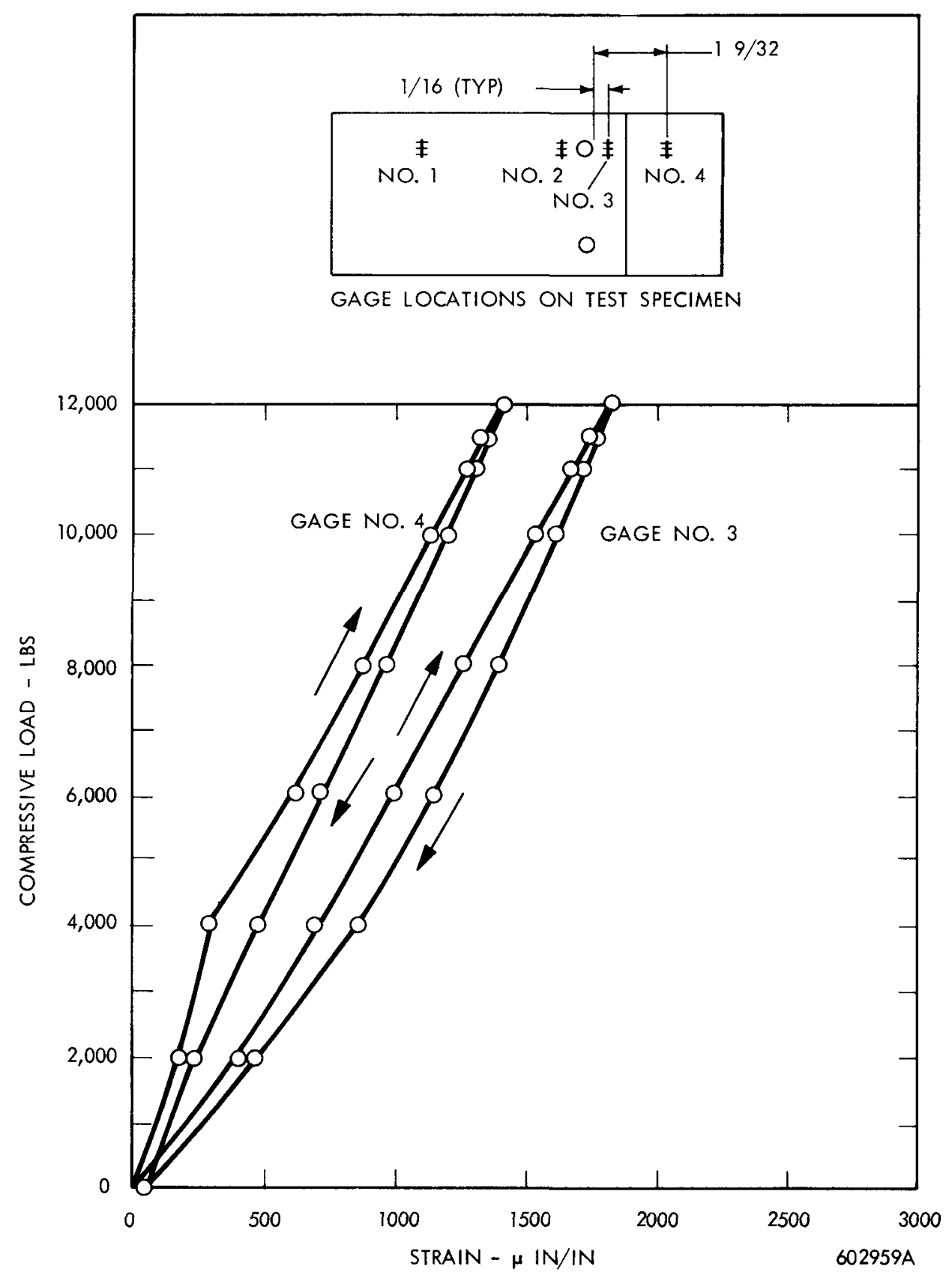

FIGURE 13

PLUNGER PIN BINDING TEST (PIN INSTALLED)

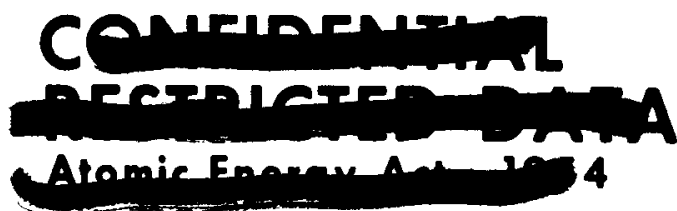



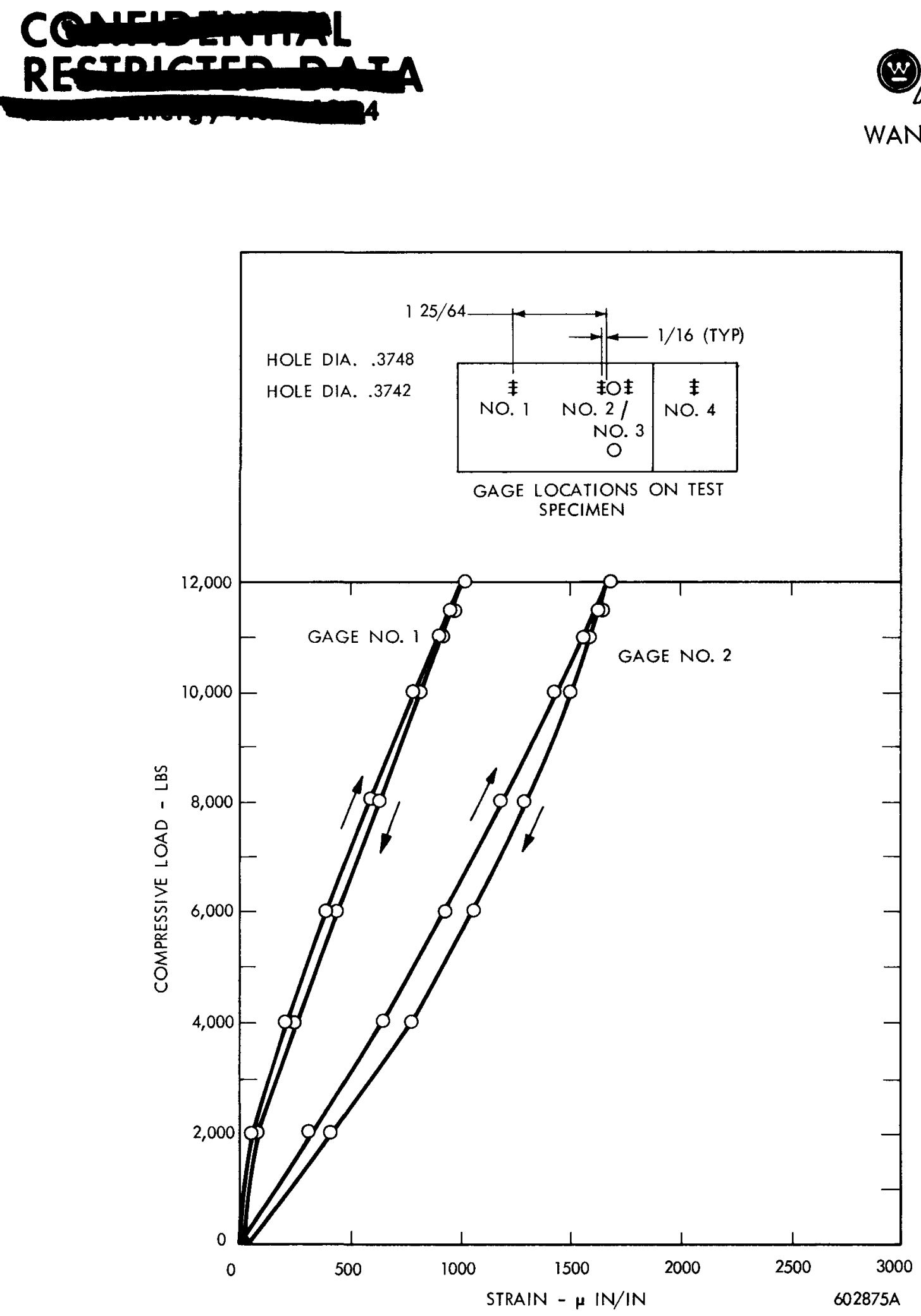

FIGURE 14

PLUNGER PIN BINDING TEST (PLUNGER PIN INSTALLED IN GAGE HOLE)

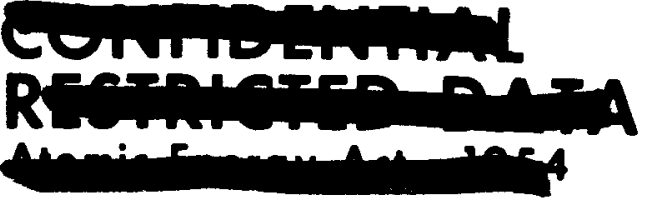



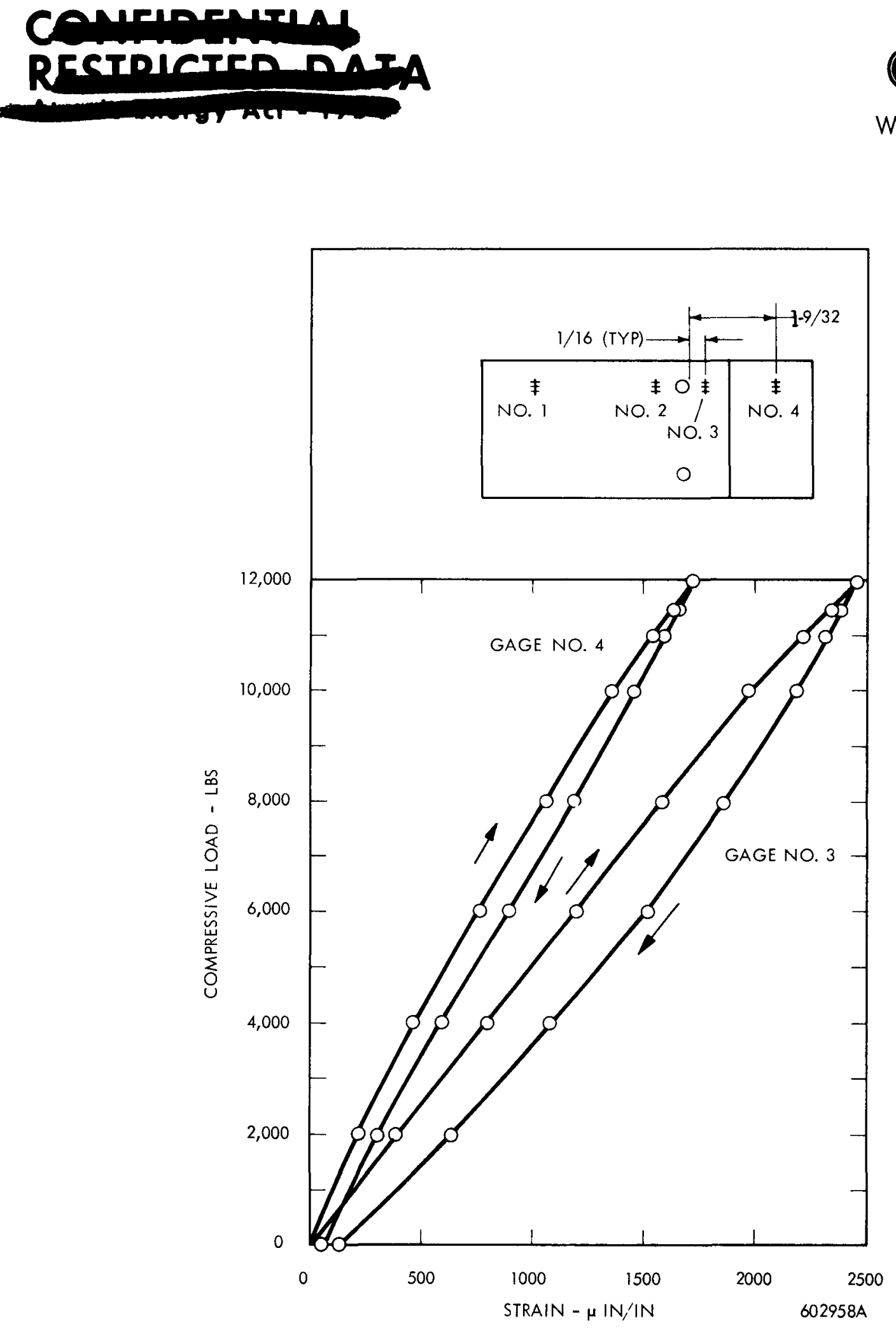

FIGURE 15

PLUNGER PIN BINDING TEST (NO PIN IN HOLE) 

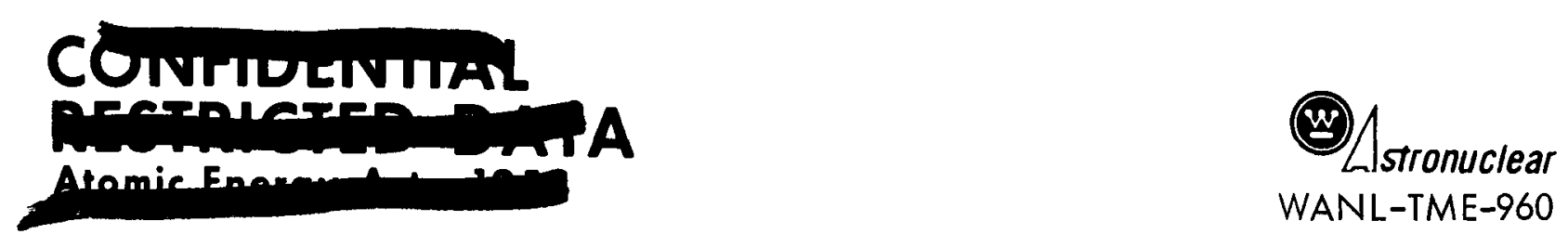

TABLE 1

NRX-A PLUNGER PIN BINDING TEST

\begin{tabular}{|c|c|c|c|c|c|c|}
\hline \multirow{3}{*}{$\begin{array}{l}\text { LOAD } \\
\text { (lb) }\end{array}$} & \multicolumn{6}{|c|}{ PLUNGER FORCE (lb) } \\
\hline & \multicolumn{6}{|c|}{ RADIAL CLEARANCE } \\
\hline & $.0001 \mathrm{in.}$ & $.0004 \mathrm{in.}$ & $.0008 \mathrm{in}$. & $.0014 \mathrm{in.}$ & $.0021 \mathrm{in.}$ & $.0026 \mathrm{in}$. \\
\hline 2,000 & 0 & 0 & 0 & 0 & 0 & 0 \\
\hline 4,000 & 15 & 0 & 0 & 0 & 0 & 0 \\
\hline 6,000 & - & 10 & - & 0 & 0 & 0 \\
\hline 8,000 & 41 & 30 & 30 & 16 & 0 & 0 \\
\hline 10,000 & 75 & 55 & 44 & 25 & 0 & 0 \\
\hline 12,000 & 98 & 81 & 80 & 35 & 0 & 0 \\
\hline 14,000 & 130 & 78 & 126 & 47 & 0 & 0 \\
\hline 16,000 & 157 & 120 & 178 & 60 & 0 & 0 \\
\hline 18,000 & 148 & 138 & 170 & 70 & 3 & 1 \\
\hline 20,000 & 187 & 159 & 178 & 80 & 12 & 11 \\
\hline 22,000 & - & - & - & - & 27 & 31 \\
\hline 24,000 & - & - & - & - & 43 & 42 \\
\hline 26,000 & - & - & - & - & 68 & 68 \\
\hline
\end{tabular}

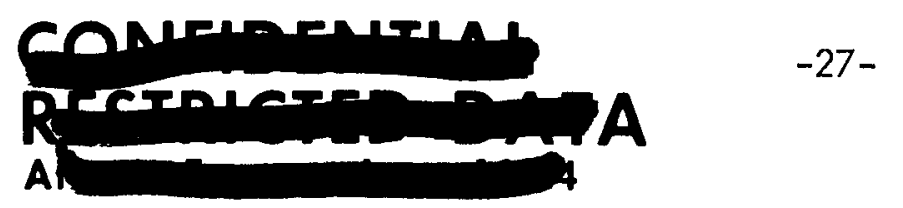




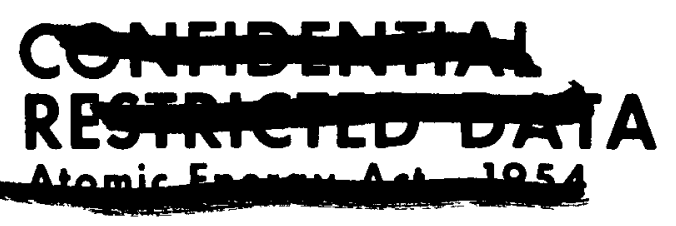

TABLE \|

PLUNGER HOLE DIAMETRAL CHANGE

$\begin{array}{rrrrr} & & \text { Outside } & \text { Center } & \text { Inside } \\ \text { Hole } 3 & \text { Original I.D. at } 0^{\circ} & .3750 & .3750 & .3751 \\ \text { at } 90^{\circ} & .3749 & .3749 & .3750\end{array}$

First Run

\begin{tabular}{|c|c|c|c|c|}
\hline Load in lbs. & Measurement< & Outside & Center & Inside \\
\hline 3,950 & $0^{\circ}$ & .3740 & .3742 & .3746 \\
\hline 7,925 & & .3729 & .3732 & .3734 \\
\hline 9,950 & & .3723 & .3726 & .3728 \\
\hline 11,025 & & .3718 & .3722 & .3726 \\
\hline 11,450 & & .3716 & .3722 & .3724 \\
\hline 12,050 & & .3715 & .3719 & .3722 \\
\hline 11,475 & & .3718 & .3721 & .3722 \\
\hline 11,025 & & .3720 & .3722 & .3725 \\
\hline 10,000 & & .3721 & .3723 & .3727 \\
\hline 7,975 & & .3723 & .3728 & .3730 \\
\hline 6,025 & & .3728 & .3731 & .3733 \\
\hline 4,000 & & .3732 & .3735 & .3737 \\
\hline 2,025 & & .3737 & .3739 & .3741 \\
\hline 1,025 & $0^{\circ}$ & .3740 & .3742 & .3744 \\
\hline 0 & $0^{\circ}$ & .3744 & .3745 & .3745 \\
\hline \multicolumn{2}{|c|}{0 (after $5 \mathrm{~min}$. ) } & .3744 & .3745 & .3745 \\
\hline
\end{tabular}

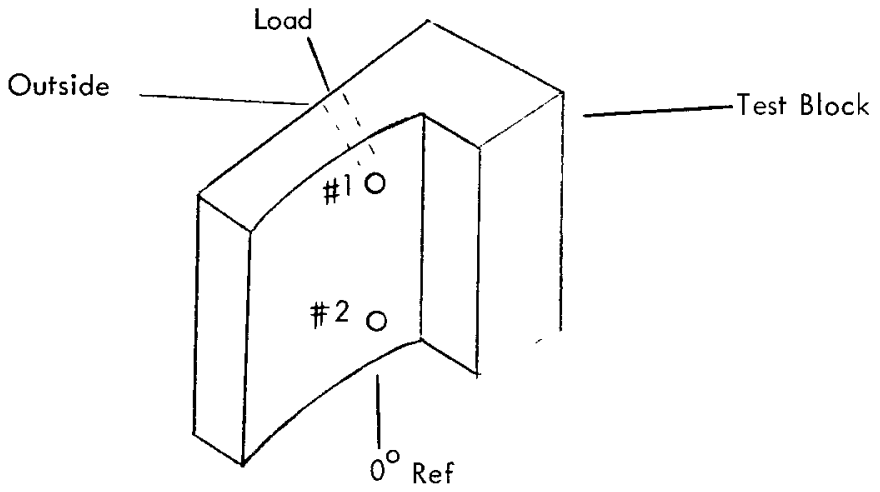




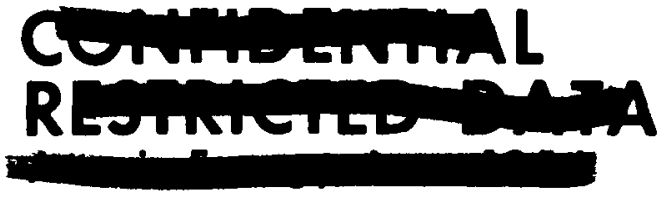

T ABLE III

PLUNGER HOLE DIAMETRAL CHANGE

$\begin{array}{lcccc} & & \text { Outside } & \text { Center } & \text { Inside } \\ \text { Hole } 3 & \text { I.D. at } 0^{\circ} & .3744 & .3744 & .3745\end{array}$

Second Run

\begin{tabular}{|c|c|c|c|c|}
\hline Load in lbs. & Measuremente & Outside & Center & Inside \\
\hline $0^{\circ}$ & $0^{\circ}$ & .3744 & .3744 & .3745 \\
2,000 & & .3739 & .3741 & .3742 \\
3,97, & & .3735 & .3737 & .3739 \\
6,000 & & .3731 & .3734 & .3736 \\
8,000 & & .3727 & .3730 & .3732 \\
9,950 & & .3723 & .3726 & .3728 \\
11,000 & & .3719 & .3723 & .3727 \\
11,475 & & .3718 & .3721 & .3723 \\
11,950 & & .3717 & .3720 & .3723 \\
11,500 & & .3718 & .3721 & .3724 \\
11,000 & & .3719 & .3722 & .3725 \\
9,950 & & .3720 & .3724 & .3726 \\
7,975 & & .3724 & .3729 & .3731 \\
6,000 & & .3727 & .3731 & .3733 \\
4,000 & & .3733 & .3735 & .3737 \\
2,000 & & .3737 & .3740 & .3741 \\
1,050 & & .3740 & .3742 & .3743 \\
0 & & .3744 & .3744 & .3745 \\
0 (after 5 min.) & 0 & .3743 & .3744 & .3744 \\
\hline
\end{tabular}

NOTE 1: Measurement accuracy is to 0.0001 inch.

NOTE 2: Hole measurements taken at 10;00 a.m. The following morning ( $12 \mathrm{hrs}$. elapsed time) showed the following dimensions:

$\begin{array}{lll}\text { Outside } & \text { Center } & \text { Inside } \\ .3744 & .3744 & .3746\end{array}$

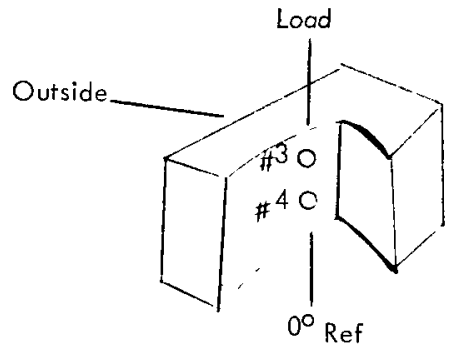

